\title{
ISLAMISM, CHRISTIANISM, URBANISM, AND THE CAPITALIZATION OF URBAN SPACE
}

\section{Elia Tambunan and Fouad Larhzizer}

Sekolah Tinggi Teologi Salatiga, Jawa Tengan, Indonesia

The Research Laboratory: Discourse, Creativity,

Society and Religions

Sidi Mohamed ben Abdellah University Morocco

email: elia.tambunan@gmail.com, fouad.larhzizer@usmba.ac.ma

Abstract: Regarding Islamic social movements as published previously, there are some fundamental mistakes made by scholars of Islamic studies. They claim rashly: Islamic social movements are manifestations of Islamism as the ideology of Islamists, the failure of Islamism has caused it to post-Islamism and the Islamic world is embracing popular Islamism that is compatible with democracy. The claim, if it is not a prayer built within the framework of da'wah, is a speculative academic claim from bias of the study of Islamic geography, not reality. This paper links Islamic studies with Christian studies and urban studies. The objects of material are religions, social movements, politics and cities in the communities of Salatiga, Central Java. The research was conducted July 2012 to July 2018 using a qualitative empirical approach with in-depth interview techniques and social media combined with literature studies have fond interesting things. Actually, Islamic social movements, especially in urban society, are far more complex than ideological issues. The relationship between religion and urban space capitalization creates contentious politics because of the interests of the urban elite who play in the local politics and urban modernization.

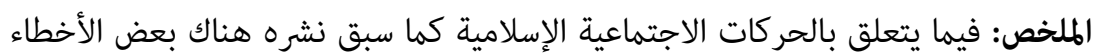

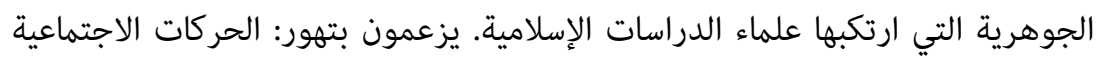
الإسلامية هي مظاهر للإسلاموية كايديولوجية الإسلاميين ، وفشل الإسلاموية أدى بها إلى نلى الإنية 
ما بعد الإسلاموية والعالم الإسلامي يعتنق الإسلاموية الشعبية المتوافقة مع الديمقراطية.

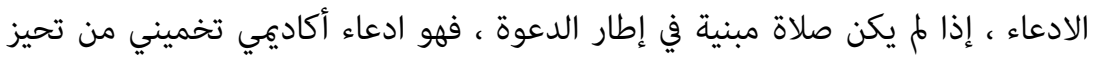

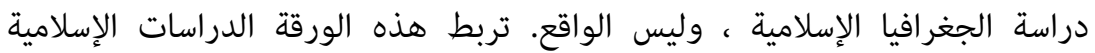

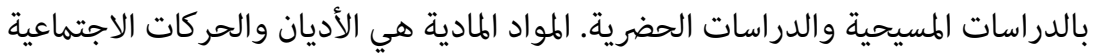

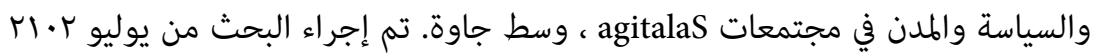

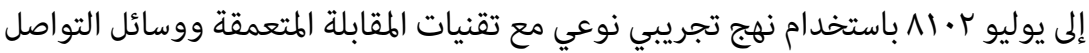

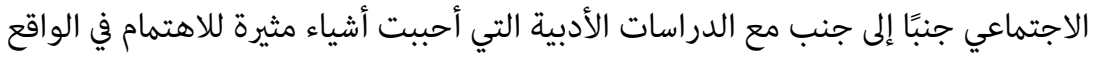

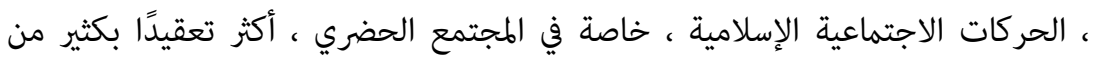

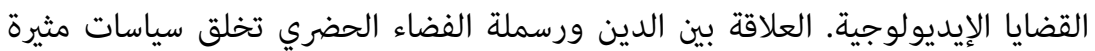

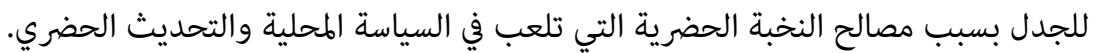

Abstrak: Terkait dengan gerakan-gerakan sosial Islam seperti dipublikasikan sebelumnya, ada beberapa kekeliruan mendasar dari para sarjana studi Islam. Mereka mengklaim terlalu cepat: gerakan-gerakan sosial Islam merupakan manifestasi Islamisme sebagai ideologi kaum Islamis, kegagalan Islamisme menyebabkan pergeseran Islamisme ke post-Islamisme dan dunia Islam sedang berada pada Islamisme populer yang kompatibel dengan alam demokrasi. Klaim itu, jika bukan doa yang dibangun dalam bingkai dakwah, adalah klaim akademik bersifat spekulatif dari bias studi geografi keislaman bukan realita. Tulisan ini mengaitkan studi Islam dengan studi Kristen dan studi perkotaan di masyarakat Kota Salatiga, Jawa Tengah. Objek material tulisan adalah agama, gerakan sosial, politik, dan kota. Penelitian dilakukan sejak Juli 2012 hingga Juli 2018 dengan pendekatan kualitatif empirik dengan teknik wawancara mendalam dan media sosial digabung dengan studi literatur menemukan hal menarik. Dalam praksisnya, gerakan-gerakan sosial Islam, khususnya di masyarakat kota, jauh lebih kompleks dari persoalan ideologis. Keterkaitan agama dengan kapitalisasi ruang kota menimbulkan politik perselisihan karena kepentingan elite urban yang bermain dalam Pemilihan Kepala Daerah dan modernisasi kota.

Keywords: Islamism, Christianism, Urbanism, Capitalizing Urban Spaces, Salatiga. 


\section{INTRODUCTION}

There is a relationship between the rising Islamism, Christianity, and city modernization. The three of them are social phenomena that occur in urban development. A social phenomenon is related to the efforts of certain urban elites to obtain political-economic benefits by employing religion. Therefore, there is no strong enough reason to believe that Islamism is only an ideological manifestation in certain groups of society as published by scholars of Islamic studies so far. Those who study Islamism do not link their analysis to the explosion of urbanization. By analyzing clearly, this paper argues that a city is a place where Islamism as a social phenomenon takes place and has a relationship with other things closely more complex matters, so it is important to be investigated further.

Unfortunately, in general, urban space as a place for Islamism to be staged is rarely given attention. Hidayaturrahman dan Sudarman said that Kyai is one of the catalysts for the establishment of political harmony in Indonesia and the involvement of religious figures in local politics never leads to conflict. ${ }^{1}$ The reason is that both of them see too much from the sociological relations side. The empirical data show that socio-religious movements are deliberately fabricated to appear ecumenical or satan, (meaning moderate) so that the surface of the city looks just fine.

Mobilizing religion into political movements in space and urban society continues to be debated. Some Christian leaders think that the involvement of Christian Pastors in the world of politics seems to be part of the mission to salt the world of politics. ${ }^{2}$ Ideally, politics is believed to be the way of ministry and the field of evangelization. According to Albion W. Small, Christian activism stems from the spirit of a national political consciousness revolution within the framework of reform movements in European cities to challenge political rights in the hands of certain church elites and to expand religious tolerance linked to the industrial revolution movement

1 Mohammad Hidayaturrahman and Sudarman, "Kyai and Political Relations Reconciling Politics and Religion in Indonesia," Al-Tahrir: Jurnal Pemikiran Islam 18, no. 2 (2018): 371-394.

2 Emmanuel Gerrit Singgih, Iman dan Politik dalam Era Reformasi di Indonesia (Jakarta: BPK Gunung Mulia, 2004), 24. 
generate political opportunities for the society. ${ }^{3}$ In the Islamic world, the emergence of Islamic social movements tends to frame in the name of religion. ${ }^{4}$

A social group that was involved in social movements by previous scholars believed more to be an ideology that was anti-political, economic, and social secular systems from the West, especially from Islamic societies. Islamism is manufactured to challenge. Islamists who adhere to this ideology articulate Islam as a holistically distinctive lifestyle in public spaces that are believed to be Islamic. Strictly, every individual and society must live piously and follow sharia as an imaginative picture of urban people. Living in social piety in it is full of symptoms of embracing a new ideology, namely urbanism. As an ideology, Peter Saunders defines urbanism as a way of urban life to legitimize class domination. ${ }^{5}$ This phenomenon must be investigated further.

This paper is the result of empirical qualitative research from July 2012 to July 2018 in Salatiga. Apart from the empirical data, this research is also strengthened by the literature. To obtain the empirical data, 168 people were interviewed. Primary data sources were obtained from several cadres of PKS and Muslims in Salatiga. They were interviewed emically to understand the multireality problems from within, as well as ethically by including the researchers' social-scientific assumptions on the reality under study. Several Pastors in Salatiga were met face-to-face to map out local political tension in Salatiga. This method is used by the researcher as a research technique to explore the tension between religious elites from within their cognition.

Meanwhile, secondary data sources were accessed from online pages about Salatiga such as local newspapers, and other literature related to research problems to give further explanations. Field and literat ure data were then analyzed to complement each other. Apart from face-to-face, interviews were also conducted by telephone and social media such as the short massages, live chats, and What Apps.

3 Albion W. Small, "The Meaning of the Social Movement," American Journal of Sociology 3, no. 3 (1897): 340-354.

4 Ahmed Afzaal, "The Origin of Islam as a Social Movement," Islamic Studies 42, no. 2 (2003): 203-43.

5 Peter Saunders, Social Theory and the Urban Question (London and New York: Routledge, 1989), 104. 
The communication technology is used to understand diction, voice intonation, physical gestures of data sources while explaining. Their body language and voice appear for a specific purpose. The data sources here are loose and roll like a snowball from one data source to another until the research problem are found settled. ${ }^{6}$

All this time, scholars of Islamic studies have been too quick to form claims from their reading of the work of social movement scholars. They carried out academic speculation arising from their religious preaching. They conclusively concluded that there was a shift from Islamism to post-Islamism. Even being published massively, the Islamic world is under popular Islamism. ${ }^{78}$ Indeed, other things are not easily denied. There is a trend in the minds of scholars of global Islamic studies to present a new intellectual discourse to understand Islam and modernity as practiced by Husnul Amin in Pakistan. ${ }^{9}$

Unfortunately, many people believe too much in Islamism studies so far. This excessive academic trust has intercepted the development of a deep understanding of religion, social movements, politics, and cities as a study material. In a certain sense, I also do not agree with the scholars of Islamic studies who say there is evidence of the failure of Islamism. ${ }^{10}$ Or vice versa, those who say that there are successes of Islamists who seek Islamism to be compatible with democracy. ${ }^{11}$ These are things that are considered to be advanced and become argumentative offers from post-Islamist scholars. To re-understand the statements made by scholars of Islamic studies and their supporting arguments, next, I will present a discussion of religion, cities in Islamic studies based on empirical data.

${ }^{6}$ Earl Babbie, The Practice of Social Research (Boston, MA: Cengage Learning, 2015), 186.

7 Asef Bayat, "Post-Islamist at Large," in Post-Islamis and the Changing Faces of Political Islam, ed. Asef Bayat (New York: Oxford University Press, 2013), 3-34.

8 Dominic M. Muller, Islam, Politics, and Youth in Malaysia, the Pop-Islamist Reinvention of PAS (London and New York: Routledge, 2014).

9 Husnul Amin, "From Islamism to Post-Islamism: A Study of a New Intellectual Discourse on Islam and Modernity in Pakistan" (The Erasmus University Rotterdam International Institute of Social Studies The Hague, The Netherlands, 2010).

${ }^{10}$ Mohammad Iqbal Ahnaf, "Tiga Jalan Islam Politik di Indonesia: Reformasi, Refolusi dan Revolusi," Wawasan 1, no. 2 (2019): 127-140.

${ }^{11}$ Greg Barton, "Political Legitimacy in Indonesia: Islam, Democracy, and Good Governance,"(New York: Palgrave Macmillan, 2011)," in Political Legitimacy in Asia. Palgrave Series on Asian Governance, ed. J. Kane, HC. Loy, and H. Patapan, 2011, 85-104. 
With Salatiga as the research location, this paper intends to answer the question, in the local political participation of the religious elite of the Islamic and urban Christian communities, why do they mobilize urbanites into political movements in the name of religion? The answer to this question in the discussion will show very clearly that the Islamic social movement as well as Christianity is a phenomenon of urbanism. Therefore, this paper will have its contribution to the study of religion in Indonesia. Scholars who are involved in the study of Islamism should integrate it with Christian studies and urban studies.

\section{RELIGION, SOCIAL MOVEMENTS, POLITICS, CITY MODERNIZATION IN ISLAMIC STUDIES}

Religion, politics, and social groups are vital to fulfilling urban needs and lifestyles. In the theory of Islamic studies, this paper places the phenomenon of Islamism as well as Christianism in religious studies which are closely related to urban phenomena as in Figure I on the next page. The Figure serves as a framework for understanding the relationship between religion, social movements, politics, and urban areas in contemporary Islamic studies. In scholarly work, Islamism or others renamed it as political Islam is used as an umbrella term that is interchangeable as an alternative to religious fundamentalism that originates from the Christian tradition and is thick with religious nuances. $^{12}$

${ }^{12}$ Noorhaidi Hasan, Laskar Jihad, Islam, Militancy, and the Quest for Identity in Post-New Order Indonesia (New York: Cornell University, 2006), 22. 
Figure I

Islamism, Christianism, and Urbanism in Islamic Studies

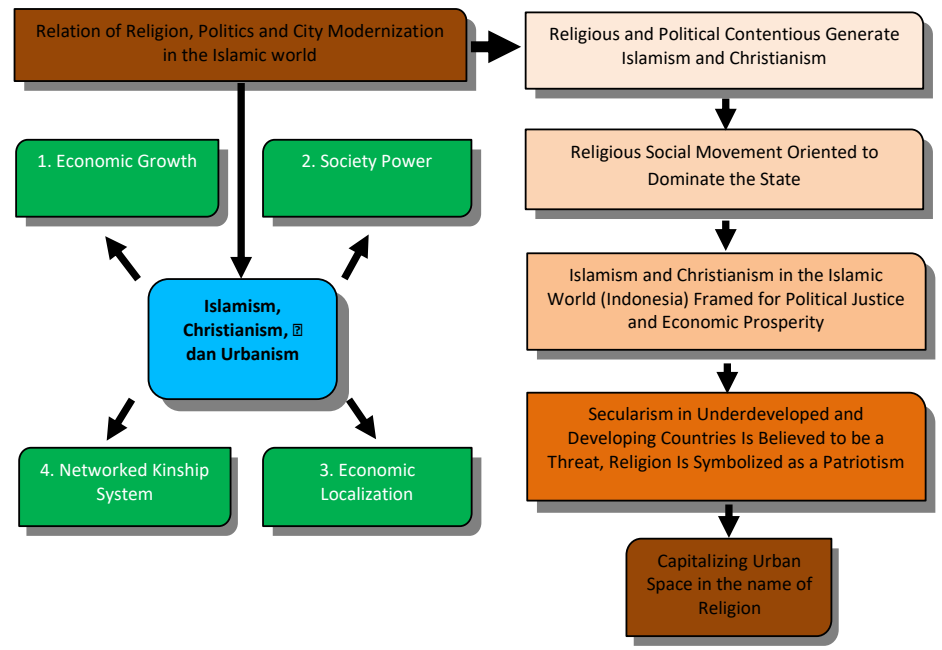

Bubalo and Fealy firmly argue that political Islam is a Western label, particularly French description of a form of activism that emerged in the early quarter of the 20th century, although the term "Islamist" became popular throughout the 1990s. ${ }^{13}$ By both, Islamism has four characteristics.

Table I

Characteristics of Islamism

\begin{tabular}{l}
\hline No. Indicators \\
\hline 1. Mobilizing the Islamic revival as the basis for community reform. \\
2. The adherents are called Islamists who understand Islam as an ideology. \\
3. The goal is to establish an Islamic system or an Islamic state (al-nizam \\
al-Islami). \\
4. Implementing sharia as social and state law.
\end{tabular}

Islamism as an ideology is closely related to the rise of Islamists in strategic positions in the public sphere. This position was embraced as a result of opening up political opportunities in the contemporary Islamic world. A phenomenon in which almost all elements of society are mobilized to the political sphere in the name of religion

${ }^{13}$ Anthony Bubalo and Greg Fealy, Joining the Caravan?: The Middle East, Islamism, and Indonesia (Woollahra, Australia: Longueville Media, 2005), 3-5. 
by social movement entrepreneurs. Whether it is those who live in the Islamic world or those who live outside for various reasons such as political exile, for instance, the clerics who aggressively mobilize Indonesian Muslim Islamic movements in Aceh, Minangkabau, Banten, Sulawesi, and Kalimantan through Islamic war literacy. ${ }^{14}$

Islamism is more accurately seen as the reaction of Islamists to the total depravity in the Islamic world they experienced at the end of the twentieth century for the sake of an apological revival of Islam. To rise, Islam is framed by political entrepreneurs as a commodity in global and local political contestation in the form of ideology so that they can appear publicly. In fact, by them, Islam was fabricated to appear compatible with democracy even though they realized that it was a foreign product. When publicizing, the political contestation of space eventually widened between Islamists and secularists but also by the other strange passenger of social movements. ${ }^{15}$ In the mobilization of Islam in urban areas, cultural elements are deliberately framed with religious symbols. To appear compatible, urban Islamists discourse the sovereignty and superiority of Islam in the form and system of the state according to the characteristics of each region. Islamism is believed to be superior to the Western model. Politicizing religion into politics found momentum at the same time as the economic growth of Islamic cities which successfully attracted Muslim youth, resulting in the explosion of urbanization. ${ }^{16}$

Meanwhile, Christianism is a pejorative sense. The term is peculiar to the Christian Right of America which means specific doctrines of Christianity created by Christian politicians. They operate the elements in Christianity into a political system in pursuit of worldly power. ${ }^{17}$ Bringing Christianity to politics was a decision made by the American Christian right two generations ago. At that time, the main vehicle was the Republican Party, although not all

${ }^{14}$ Elia Tambunan, "Indonesian Islamism: The War of Islamic Literacy from Millenarism to Radicalism," Akademika 24, no. 1 (2019): 1-38.

${ }^{15}$ Muhammad Ansor, "Post-Islamism and the Remaking of Islamic Public Sphere in Post-Reform Indonesia," Studi Islamika 23, no. 3 (2016): 471-516.

${ }^{16}$ Bilal Ahmad, "Urbanization and Urban Development in the Muslim World: From the Islamic City Model to Megacities," GeoJournal 37, no. 1 (1995): 113-123.

${ }^{17}$ Andrew Sullivan, "Christianity vs Christianism, Love vs Power," The Atlantic, 2009. 
of them were completely partisans, meaning party members. As a result, Americans who live a worldly life are drawn to political power when the era of Christian fundamentalism is at its peak in the country. At that time, as Christians and Jews, as well as Muslims, have attempted to seize the power of government and law, engage in physical warfare to reinforce their literalist beliefs. Religious battles took place increasingly fierce and became inevitable. Meanwhile, Christian fundamentalism is an American Protestant movement. This movement has also existed previously in Great Britain, emerging in the late 19th century as a reaction to theological modernism. Fundamentalism aims to revise traditional Christian beliefs to accommodate new developments in the natural and social sciences, especially the influence of the biological theory of evolution. ${ }^{18}$

Urban theorists such as Lewis Mumford said the city is a node of power and culture of one community. Cities have special characteristics of the desires of urban elite groups. ${ }^{19}$ With fierce competition and growth, cities in the world have formal authority within the framework of the ruling government to reclaim any relation to the democratic process and progress that anyone promotes. ${ }^{20}$ Therefore, cities should be seen as places where strong social pressure, ambitions of social groups, human interests in it are available. ${ }^{21}$

Conflict of urbanites is related to the momentum of economic growth, as a result, urban space always faces shocks, especially from newcomers. In essence, the urban space both academically cannot be seen as a stable place, especially politically. The development of cities in Indonesia always follows the tastes of politicians, urban elites and religious elites, and traditional elders, although the space of Indonesian cities is very much needed, especially for the middle class. By relying on the Indonesian-style kinship system which tends to be collusive, they are active in political movements to gain greater

${ }^{18}$ Ernest R. Sandeen, The Roots of Fundamentalism: British and American Millenarianism 1800-1930 (Chicago: University of Chicago Press, 2008), 3-59.

${ }^{19}$ Lewis Mumford, The Culture of Cities (New York: Harcourt, 1938), 104.

${ }^{20}$ Richard Schragger, City Power: Urban Governance in a Global Age (New York: Oxford University Press, 2016), 1, 15, 46, 253.

${ }^{21}$ Goran Therborn, Cities of Power: The Urban, The National, The Popular, The Global (London and New York: Verso, 2017). 
access to state resources. ${ }^{22}$ Urban space, said Tompkins, both socially, economically, and politically, is like a theater full of contestation. Urban life is very theatrical..$^{23}$ The city, according to Allen, Massey, and Pryke, is one open living space. The various types of relationships within it, even with very different people whose social identities intersect, compel each group to find its place as economic resources in which the place of economic growth is localized. ${ }^{24}$

In understanding the theory above, Islamic cities can no longer be read-only as sociological and accommodating arenas. Secretly, the people in it are increasingly pressed by financial needs. Unfortunately, scholars of Islamic studies have not paid serious attention to this issue. It happened because they were too focused on religious data. The urbanization boom in Islamic countries requires a large living space. The limited space available, although not desirable, creates conflicts of interest among Muslims, especially those who are educated but financially weak and in power. As a result, they frame religion and are packaged as commodities.

\section{THE URBAN POLITICAL MOVEMENT}

By learning empirical data from Salatiga, I found that one thing that strengthens the dynamics of urban political movements in Indonesia, as measured by democratic participation in the General Election (Pemilu) and Regional Head Elections (Pilkada) events, what happens is the capitalization of urban space. The character of the capitalization is determined by the interests of the spatial authorities who have access to the state and the city center as a source of livelihood. Urbanization that continues to strengthen is a challenge for those who have occupied the city first. As a result, the city is not a stable place. Cities are always rocked by new challengers. This has an impact on the distribution of economic-political power and the

${ }^{22}$ Gerry van Klinken, "Introduction: Democracy, Markets, and The Assertive Middle," in Search of Middle Indonesia: Middle Classes in Provincial Towns, ed. Gerry van Klinken and Ward Berenscho (Leiden and Boston: Brill, 2014), 1-34.

${ }^{23}$ Joanne Tompkins, Unsettling Space: Contestations in Contemporary Australian Theatre (New York: Palgrave Macmillan, 2006), 18.

${ }^{24}$ John Allen, Doreen Massey, and Michael Pryke, "Introduction," in Unsettling Cities: Movement/Settlement, ed. John Allen, Doreen Massey, and Michael Pryke (London and New York: Routledge in association with The Open University, 1999), 1. 
position of strategic groups of urban community elites, as happened in Salatiga.

As seen from the surface, Salatiga is a city in Java, Indonesia which is doing well despite its limited land area. Salatiga is categorized as a Medium City. ${ }^{2526}$ The latest BPS statistics update on June 20, 2020, the city's population is 194,084. Geographically, Salatiga is a city with a relatively small area. It is right in the middle of the Semarang Regency area. Until 2020, the area of the City of Believers is only $5,678,110$ hectares or $56,781 \mathrm{~km}^{2}$. Administratively, the City of Salatiga is divided into 4 districts with 23 sub-districts, namely Argomulyo: 6 sub-districts, Tingkir: 7 sub-districts, Sidomukti: 4 sub-districts, Sidorejo: 6 sub-districts. The narrow land of Salatiga has created contentious politics that describes who has the most right to live in the city and who feels the most entitled to be called Salatiga City People. Generally, contentious politics are related to the allocation of urban land for social, economic, and political life between community groups.

The contentious politics is the conflicting interactions between elites for making public claims. Several people, organizations, and even state governments are involved in claiming their truth because there are interests. ${ }^{27}$ In contentious politics, actors make claims over the interests of others. ${ }^{28}$ This definition describes the involvement of Christian and Muslim communities in local political events in Salatiga. Christian involvement in politics can no longer be believed to be limited to providing votes, aspirations, and political rights represented by Christian parties or nationalist politicians who have been very historical since Indonesia's independence. ${ }^{29}$ Until now, the

${ }^{25}$ No rigid standards regarding the size of a small town. P. van Liddert and O. Verkoren, Small Towns and Beyond: Rural Transformation and Small Urban Centres in Latin America (Amsterdam: Thela Publishers, 1997), 3.

${ }^{26}$ But a medium-sized city is defined as having 25,000-100,000 inhabitants. J.E. Hardoy and D. Satterhwaite, Small and Intermediate Urban Centers: Their Role in Regional and National Development in the Third World (London: Hooder and Stoughton, 1986), 13-15.

${ }^{27}$ Doug McAdam, Sidney Tarrow, and Charles Tilly, Dynamics of Contention (Cambridge, UK, and New York: Cambridge University Press, 2001), 5.

${ }^{28}$ Charles Tilly, Contentious Performances (Cambridge: Cambridge University Press, 2008), 5.

${ }^{29}$ Political Christianity is not only limited to identity but can also be an affirmation that Christian political movements for Indonesian independence have 
Christian community was also in political activism. They mobilize the power of internal group networks and direct other parties they find to politics. Secretly and openly, they support and elect politicians and even get involved in signing political contracts.

In literature, generally, Christian pastors are not allowed to campaign for the choice of candidates from the pulpit. However, in orthopraxis, after church meetings are over, or through home Bible study meetings, congregations are very free to discuss political choices. Whatever the debate, the activity is mobilizing. The congregation is directed to elect politicians according to Christian identity and interests. On another understanding, the mobilization and direction of social groups into political movements is a free, open, and loose activity in Christian society. Such political activism is a valid reason for Me to call them political Christians. Christianity is used as an ideology, namely Christianism. Christian society is loosely even as kinship as something naturally mobilized into politics. One of the data about the Salatiga Christian political community can be found in the Fellowship \& Servant of God Frontline Services (Persekutuan \& Pelayanan Hamba Tuhan Garis Depan, abbreviated as PPHTGD). Although they did not try to place themselves and their representatives in the people's assembly. However, they had a strong desire to have someone on the arm who could influence the competent government agencies to produce decisions in their favor. After all, groups of people who are active in political affairs are political interest groups. ${ }^{30}$

The problem of urban space capitalization affects how Salatiga people become political Muslims or political Christians. Based on interviews with pastors from churches outside the mainstream, since entering the Reformation until 2020, in this city, there are 7 conflicts of interest in the city's money between Islam and Christianity. The conflict did not end in small-town wars as happened in other small cities such as Poso, Ambon, North Maluku, West Kalimantan,

been carried out by Christians. Indonesian independence is not a gift or effort from a certain group but is a gift from God through the struggle of all Indonesians. Samuel Benyamin Hakh, "Peranan Orang Kristen dalam Pusaran Politik di Indonesia," Jurnal Ilmiah Musik dan Agama 2, no. 1 (2018): 1-17.

${ }^{30}$ Anthony J. Nownes, Interest Groups in American Politics: Pressure and Power (New York: Routledge, 2013), xi. 
and Central Kalimantan in 1997-1998 for example. ${ }^{31}$ The churches that experience urban space conflicts are the Assemblies of God Kembang Arum Church, Rt 3 Rw 6, 2002, the Rt 2 Rw 5 Bancaan Prayer Fellowship, Sidorejo Lor in 2005, White Cross land, 2007, Pantecostal Church in Indonesia Argomas Housing J1 . Argotirto No. 10, 2004-present, Argo Rumekso Indonesian Bethel Church Jl. Argo Rumekso No. 22, 2010-present, Indonesian Christian Church Nazaret Jl. Sidomulyo Rt 4 Rw 6 Ngawen, 2010-present, Sidorejo Church of Christ Indonesia, 2014-present.

Along with city contentious political, the Salatiga Islamist community, especially the congregation of several political clerics who have kinship at least friendship draws a strict demarcation line with Christianity are the intellectual actors behind the capitalizing space. ${ }^{32} 33$ They want church lands to be more suitable for social activities such as the establishment of an Islamic Center or Islamic education and training centers that are considered more useful. According to the perception of the political clerics, land ownership in Salatiga city will be very able to mobilize them to emphasize the presence of Islam in public. ${ }^{34} 35$ The hidden meaning behind the data is that the Ulemas are still the center of the foremost network of urban power in the Muslim world. In this case, it appears that Pastors are trying to defend their rights to city space in the name of Christian activism, as their perception, because that is the source of their life in the framework of religious philanthropy.

Even though it didn't get covered in bloodshed, out of the seven cases, I want to say, in the daily life of urban people, the capitalizing space is something unique. Michael Dumper emphasized that the dimensions of urbanism in the world's holy cities conflict with interest in the name of religion..$^{37}$ According to C.E. Bosworth, the struggle for urban land is very historical in the development of

${ }^{31}$ Gerry van Klinken, Communal Violence and Democratization in Indonesia: Smal Town Wars (London and New York: Routledge, 2007), xvii.

${ }^{32}$ Matheus Sukary, "Interview" (Salatiga, August 2, 2015).

${ }^{33}$ Stefanus Sugito, "Interview" (Salatiga, August 2, 2016).

${ }^{34}$ Sudirja, "Interview" (Salatiga, October 11, 2016).

35 Jahroni and Yairoh, "Interview" (Salatiga, November 2, 2016).

${ }^{36}$ Fauzi Untung Suwarno and Wife, "Interview" (Salatiga, November, 2016).

${ }^{37}$ Michael Dumper, "Introduction: The Urban Dimension of Religious Conflicts," in Contested Holy Cities: The Urban Dimension of Religious Conflicts, ed. Michael Dumper (London and New York: Routledge, 2019). 
cities in the Islamic world. ${ }^{38}$ Islamism, Christianism, and Urbanism are internal problems in the Islamic world. The Islamic community elites have attempted to mutually redefine public space in the name of religion mixed with local culture, ${ }^{39}$ such as the conflict between the local Bugis-Macassans in Kupang, East Nusa Tenggara in 1998, and religious issues in Flores between 1991-1995..$^{40}$ Firmly, there is a correlation between the rise of Islamism and Christianism with the modernization of urban areas. The presence of Islamists and Christianists through the roles they play in local politics has a direct impact on the development of the urban areas in which they live. As a result, urban space is one place that is never stable.

In a city space that continues to be shaken by political conflicts, Pastors are not free to build a church and to occupy itas worship for the congregations they serve even though the land beneath them has been bought. Supposedly, the land had become property rights and even usage rights. The data on the Salatiga conflict would like to say that in urban communities there is a reality of Christian discomfort as fellow cities among other communities. Later, in the political movement, the Salatiga conflict will continue to be turned on as a political narrative, especially during the Pilkada, both from 20112016 and 2017- (2022). The number of Salatigans' involvement in the 2011 Pilkada is quite good, as much as $80 \%$, increasing to $85 \%$ in $2017 .{ }^{41}$ Conflict narratives have always been induced in urban political activism. This provides an overview of how religious people perceive the identity and religion of others. The domination of religion of the past often returns as a nightmare that is still burdensome and cannot be overcome by rational analytical power but in elections that must benefit certain groups. ${ }^{42}$ In other words, community involvement in politics is often stronger to pursue political interests in urban space so that it is very vulnerable to generate horizontal conflicts.

${ }^{38}$ Clifford Edmund Bosworth, "Editor's Introduction," in Historic Cities of the Islamic World, ed. Clifford Edmund Bosworth (Leiden and Boston: Brill, 2007), xixiii.

${ }^{39}$ Kayla Branson, "Islamist Cyber-Activism: Contesting the Message, Redefining the Public," The Journal of North African Studies 19, no. 5 (2014): 713-32.

${ }^{40}$ Philipus Tule, "Religious Conflicts and a Culture of Tolerance: Paving the Way for Reconciliation in Indonesia," in Prosiding Simposium Internasional Jurnal Antropologi Indonesia I (Makassar, 2000), 518-528.

${ }^{41}$ Suryanto, "Interview" (Salatiga, February 10, 2014).

${ }^{42}$ Haryatmoko, "Formalisme Hukum Dan Rasa Keadilan," Kompas, 2015, 6. 
What interesting is, although there is still conflict, the Christian community continues to carry out religious activities. This data would say, there were no problems in the city as if. However, at the same time, it is only an effort chosen by the Christian community to maintain the image of Salatiga as one of the tolerant city in Indonesia. The public imagination is about to be fooled, that the city of Salatiga has no problem. Clear strongly, tricking the shared imagination becomes a rational choice for urbanites. It was deliberately chosen because it has a positive impact on the tranquility of living together on the surface of the city. Rational choice is important in the political movement of urban society. However, what can never be ignored is that the discriminatory treatment experienced by the Salatiga social group has never been resolved for a very long period.

In theory, social movements can be seen, conflict can make emotional ties and kinship networks of certain community groups tighter and stronger. They have the same viewpoint of what is experienced. They finally gave rise to identity-fighting politics, a political stream that involved a person or group of people who had similar characteristics. ${ }^{43}$ This theoretical perspective was what happened in Salatiga's Christianity and was then promoted in the Salatiga PPHTGD body. They rationally use religious identity as a means of resistance and a frame for the capitalization of urban space. Instead of raising political resistance, they built a political alliance with Islamists through binding political contracts. More interestingly, it turns out that the Islamists also welcome it. They appear in public through the frame of political friendship to impress many people.

Pilkada in Indonesia is cinematic political activism. Filmmakers and actors are performing in it. On Thursday, April 7, 2011, in the momentum of the Salatiga regional election campaign, Candidate Pairs (Paslon) Yuliyanto and Muh. Haris is abbreviated as YARIS. The Paslon visited Catholic community leaders at the St. Paulus Miki Church at Diponegoro No. 34. They also extended political safaris with the frame of friendship (Silaturahmi) among Salatiga figures. They visited Christian leaders who are members of the Salatiga Christian Churches Cooperation Agency (Badan Kerjasama Gerejagereja Kristen Salatiga, shortened by BKGS). What is hidden as a

${ }^{43}$ Sri Astuti Buchari, Kebangkitan Etnis Menuju Politik Identitas (Yogyakarta: Yayasan Obor Indonesia, 2014), 26-89. 
public political message from the political Silaturahmi and safaris is that there are still religious conflicts embedded in the memory of the Salatigans that have not been resolved. However, there is an implicit positive message that the two Candidates want to deliver to the structural elite of the religious community guarding the city's morality, namely that both are ready to bring their aspirations to the stage of completion with responsible completeness. Although, Zamsiri, PKS cadres, and politicians are also a special religious leader (Modin) for the Sidomukti sub-district, said that friendship must also be realized in the frame of a political mantra to mobilize Christian public political participation in democracy. ${ }^{44}$

Political cinema and filmmakers in Indonesia have their statistical logic and political calculations. According to data on the BKGS website, in Salatiga alone there are 97 churches registered as official members. ${ }^{45}$ If averaged out, there are about 328 Christians in one church, for a count of 31,829 divided by 97 . Hence, judging by these statistical assumptions, it is no wonder any Candidate wants to embrace Christians when the political campaign season arrives. It is very reasonable to claim that the political market is called the church congregation. The commodity is religion wrapped in a package of social harmony and tolerance for Indonesians. The reality of the Christian social composition in the city of Salatiga as many as 31,829 people and Catholics with 9,521 people is also very legible. The political bargaining position of the Salatiga Christian congregation is very significant. The political visits conducted by the YARIS showed that they were statistics servers. They also cleverly play political calculations so that they are used as a basis for consideration in forming political alliances, one of which is through political contracts. YARIS also involved Christians as the Campaign Team in the Data and Information Sector, which was held by Yani Rahadja, SE, MM. He is a congregation of the United Pentecostal Church in Indonesia, and Yakub Adi Kristanto, SH, MH who served in the Law and Advocacy Sector for the 2017- (2024). Yakub is also known as a member of the Indonesian Bethel Church on Hasanuddin Salatiga.

\footnotetext{
${ }^{44}$ Zamsiri, "Interview" (Salatiga, September 12, 2016).

${ }^{45}$ Badan Kerjasama Gereja-gereja Salatiga, "Members," bkgssalatiga.com, 2015.
} 


\section{ISLAMIC AND CHRISTIAN POLITICAL ALLIANCE}

Driven by the economic-political interests of urban space, at certain times, the urban social groups that are different in many ways can build political alliances. In Salatiga, several Pastors from PPHTGD Salatiga entered into a political contract with the YARIS who are seen as representing the Salatiga Muslim community. However, PPHTGD Salatiga cannot be denied as a representation of Christian community. Prosperous Justice Party (Partai Keadilan Sejahtera, or PKS) cadre Latif Nahari, who is now a member of the Salatiga Regional People's Representative Assembly (Dewan Perwakilan Rakyat Daerah, known as DPRD) for the 2014-2019 period and remains elected in the 20192024 period from the Sidorejo District, said, we PKS no longer see one's religion and do not question religion. According to him, what and who is better at seeing the welfare that PKS can do together for the Salatiga community is much more important. Then, building an Islamic and Christian political alliance by signing a political contract with any community group is common. ${ }^{46}$ Latif statement cannot be seen as an example of a shift in behavior in Islam in terms of local politics ${ }^{47}$ or the contestations for influence between post-Islamist and apolitical cultural Islam. ${ }^{48}$ What happens in Islamism is a shift in interests towards other people which gives political advantage as a point of view.

In democratic theory, political contracts are read as a sign that there is a reality of discontent living in society. A political contract cannot be interpreted as a social agreement or a social contract which states that a person or group of people gives up the right to power to an agreed person or institution so that the source of state sovereignty comes from the people through a social contract between two parties. ${ }^{49}$ A PKS politician Nono Rohana from the Tingkir district is now a member of the Salatiga DPRD for the 2019-2024 period, seeing the opposite. He feels comfortable living and being a Salatiga

${ }^{46}$ Latif Nahari, "Interview" (Salatiga, February 6, 2014).

${ }^{47}$ Zainuddin Syarif, "Pergeseran Perilaku Politik Kiai dan Santri di Pamekasan Madura," Al-Tahrir: Jurnal Pemikiran Islam 16, no. 2 (2016): 293-311.

${ }^{48}$ Akhmad Rizqon Khamami, "Erdogan Versus Gulen: Perebutan Pengaruh antara Islam Politik Post-Islamis dengan Islam Kultural Apolitis," Al-Tahrir: Jurnal Pemikiran Islam 16, no. 2 (2016): 247-266.

${ }^{49}$ G.H. Sabine, A History of Political Thought (New York: Collier Books, 1959), $247-266$. 
person because he has established good relations with all groups of people. ${ }^{50}$ PKS cadres played this reason to establish contact with any people groups or political parties.

In the election of Salatiga local leader, PPHTGD Christians supported YARIS despite being promoted by a coalition of Islamists and nationalists, namely Prosperous Indonesia Party (PIS), Prosperous Justice Party (PKS), United Development Party (PPP), and Democratic Party (PD). In PPHTGD's perception, Muh. Haris is a representation of the Islamic identity, icon, figure of Salatiga. Indeed, the PKS “political congregation" was largely from the Islamic social groups of Nahdlatul Ulama and Muhammadiyah. Haris is also a PKS national cadre. It seems that PPHTGD (like some other Islamic groups in Indonesia such as Gusdur for instance) perceives that PKS is an Islamic movement to fight for an Islamic state. Many people still perceive PKS with its entire political network as "the enemy in the blanket." ${ }^{11}$ PKS calls itself an open party, with populist-humanist issues through language and universal political communication when appearing in public. Contrastly, the political Islam movement within PKS is always believed to be a social movement and political party that has an agenda of Islamizing the state and society. To a certain degree, by young Indonesian Christian, PKS is still considered to be alive in pseudo-democratic Indonesia as a political strategy. The concept of "Non-Muslim" in their socio-political discourse is still a question. ${ }^{52}$ Even by fellow Islamic groups, Silently, PKS continues to be regarded as Allah's party with an Islamist mission to implement Islamic law in society. ${ }^{53} 54$ With such public perceptions in the Christians, these icons, figures, and PKS must be tied by political

${ }^{50}$ Nono Rohana, "Interview” (Salatiga, February 28, 2014).

${ }^{51}$ Abdurrahman Wahid, "Pengantar Editor: Musuh dalam Selimut," in Ilusi Negara Islam: Ekspansi Gerakan Islam Transnasional di Indonesia, ed. Abdurrahman Wahid (Jakarta: The Wahid Institute dan Maarif Institute, 2009), 11-41.

${ }^{52}$ Hans Abdiel Harmakaputra, "Islamism and Post-Islamism 'Non-Muslim' in Socio-Political Discourses of Pakistan, the United States, and Indonesia," Al-Jamiah 53, no. 1 (2015): 180-204.

${ }^{53}$ Haedar Nashir, Manifestasi Gerakan Tarbiyah: Bagaimana Sikap Muhammadiyah? (Yogyakarta: Suara Muhammadiyah, 2007).

${ }^{54}$ Haedar Nashir, Islam Syariat: Reproduksi Salafiyah Ideologis di Indonesia (Bandung: Mizan Kerjasama dengan Maarif Institute for Culture and Humanity, 2013). 
contracts. Political contracts as a democratic way to anticipate all Islamic movements. ${ }^{55}$

There is an assumption, local politics is the most appropriate momentum to domesticate the Islamist movement. According to PPHTGD, the Salatiga Islamist movement is encapsulated in Yuliyanto and Muh. Haris. The implementation of Islamic ideology in the PKS party into the life of the Salatigans, they think will only benefit Islam. Christians perceive that the knot point needs to be legally locked. On the other hand, when Islamists come to power in Salatiga, they will remember Christian contributions to the victories and political power they have won. For PPHTGD, entering into a political contract with Yaris is political anticipation for all possibilities that occur. However, at the same time in other Salatiga Christian which is represented byBKGS, the emergence of PPHTGD on the local political stage is positioned as a pressure group that creates an enclave. PPHTGD is labeled as a new layer in the history of the mission and the ecumenical movement in the Salatiga Christian which is considered foreigners. Political contracts are considered to have tarnished the image of the church and Christians in Salatiga. They are considered disloyal to the mainstream church's authority because they have different preferences. By the main churches, by several Christian leaders, religion has become a political instrument. ${ }^{56}$

In terms of Salatiga Christianism, the political contract signed by the then chairman of PPHTGD Salatiga, namely Yusuf Sunari, believes from another side. Meanwhile, from the Islamist, it was signed by H.D. Haryoko RD, also has its agenda. The two figures are people who feel they represent Christianism and Islamic. The contract contains five points that can be said to be the political promises of the YARIS to the urbanites. If elected as Mayor and Deputy Mayor of Salatiga, YARIS will do the following 5 things: (a), protect the City of Salatiga in a diversity of religions, ethnicities, races, and groups, (b), provide freedom and a sense of security for all people of religion and belief respectively, (c), make it easy for Christians to build places of worship and are allowed to use public spaces for religious celebrations, (d), together with the community to foster tolerance between religious communities in the City of Salatiga, and

\footnotetext{
${ }^{55}$ Yusuf Sunari, "Interview” (Salatiga, July 30, 2015).

${ }^{56}$ Ebenheser Lalenoh, "Interview” (Salatiga, July 21, 2015).
} 
(e), none discrimination in providing public services and access to the use of Regional Revenue and Expenditure Budget (APBD) for the benefit of all religious communities.

Islamic and Christian political alliances arise because of widespread discontent. The political idea behind the political contract underlines the real discontent living of urbanites. The process of drafting a contract based on the results of interviews that have been conducted with political actors will justify the inconvenience. The contract is precise as a means of acquiring spaces in the city area symbolically. Not very strong in terms of democratic affairs at the local political level. Indeed, many Pastors in PPHTGD say they have gained nothing more than to increasingly allow them to defend public rights. As Salatiga Christians, they still have the freedom to worship. Like in Pancasila City Square, there are celebrations of religious holidays such as Easter and Christmas. Besides, they have received Christmas gifts and greetings from the Mayor and Deputy Mayor regularly since Yuliyanto and Haris took office. They admit that the parcel delivery is a new experience as a Christian Pastor that has never been obtained before even though the Mayor or his Deputy is a Christian. However, some of the PPHTGD Pastors explained carefully, the political contract is a means of control for the Islamists and the agenda for the Islamizing Salatiga.

The actor behind the Islamist and Christian political contracts in Salatiga is not Sunari. The political ideas when making the contract came from Elizabeth Dwi Kurniasih Yustinus Parito. She is a young politician born in Salatiga on June 26, 1975, a Catholic, also a member of the Salatiga City DPRD in 2009-2014 from the Indonesian Unity Justice Party (PKPI) in the Argomulyo District. She lives on Manggasari N0. 48, Tegalrejo, Salatiga, also Alumnus from the Law Faculty and the Development Studies Postgraduate Program, both from Satya Wacana Christian University. After no longer making it to the DPRD for the next period, Elisabeth married and moved to Subang, West Java. Luckily, data can be obtained from her younger siblings, Alex, and father, Petrus. Alex Yustinus Parito, who once ran for the 2014 Salatiga DPRD as PKPI Party candidate but did not elect. Petrus Yustinus Parito, the biological father of Elisabeth and Alexis also the Success Team for his children. Three of them were political actors in the draft political contract. 
For Christians, a political contract is a control mechanism for Islamic parties and Candidate as well as an Islamic society. For most PPHTGD Pastors, which has 104 members, some of whom live in Semarang Regency, PKS is a violent Islamist political movement. This party, by Alex, is still believed to carry the agenda of changing Pancasila as the Indonesian ideology to Islamism. The Islamist movement needs to be controlled because it is dangerous for Indonesia. ${ }^{57}$ Furthermore, Petrus explained. Politics and religion must be separated. For him who feels the representation of the Catholic Salatiga, Islamism as the principle of PKS cannot become the legislation of city government regulations. "A political contract is an agreement to regulate the religious life of Salatiga. Islam as a religion must be respected, but if Islam is applied as public law, then we will oppose it," as said Petrus. ${ }^{58}$

On Islam's hands, in terms of political diplomacy, for YARIS, a political contract aims to emphasize political commitment. Signature is proof of commitment to a life together. The hidden message of this commitment is influenced by the fact that the economic situation of the Salatiga Islamist community is much weaker in the economic sector when compared to Christian society. This weak economic position has historical links. One of the reasons for the weakness of the Islamic economy was because the Dutch discriminated against racism in Salatiga from 1442 to 1917. The bad consequences of industrial liberalization in colonial cities of Indonesia were that the state placed Islamic communities living in the suburbs as plantation workers owned by private entrepreneurs and the government Netherlands. ${ }^{59}$ Firmly, making a political alliance with anyone to win the Pilkada is important for the management of urban space which will be vital to improving the level of the Islamic economy.

In terms of gaining constituent, political contracts have meaning for PKS. The party has an interest in opening a new base in Salatiga. On the official website of PKS, the City of Salatiga is recognized. There was news, "Ending the National Campaign in Salatiga and Solo,

\footnotetext{
${ }^{57}$ Alex Yustinus Parito, "Interview” (Salatiga, August 1, 2015).

${ }^{58}$ Petrus Yustinus Parito, "Interview" (Salatiga, August 1, 2015).

${ }_{59}$ Abel Jatayu Prakosa, Diskriminasi Racial di Kota Kolonial Salatiga 1442-1917 (Semarang: Sinar Hidoep, 2017).
} 
PKS Targets Central Java to Become a New Base."60 The political contract is a strategic effort to attract new voters in Semarang. On one side, the aim is broader, considering that the PPHTGD operational network area also extends to other areas outside Salatiga. PKS wants to send the public messages, even though it holds as an Islamist party, it is open to collaborating with anyone in the political frame of national progress. Despite being a newcomer, PKS is trying to convince the enemies of political Islam.

\section{CONCLUSION}

Salatiga data, Central Java, Indonesia where this research was conducted, argue religious and Muslim and Christian community elites in urban areas in political participation mobilize political movements in the name of religion to redefine the place where they live from an economic-political point of view. They become aware that urban spaces are not only for living and practicing religion. Capitalizing the city is important as a way to fulfill the lifestyle of the urban people who are all full of economic-political calculations. An attempt to redefine the city is more than just matters of religion, politics, and democracy. Salatiga presents another political panacea. Islam and Christianity form political alliances but from an economic-political perspective of urban space. The involvement of other identities does not have to be pushed aside, instead, it must be approached. The appearance of Islamism and Christianism in the public arena through political contracts is also a conscious effort. It a way of political struggle to limit and control state power and access that is in the hands of other groups. Thus, political contracts do not synergize with people's sovereignty as understood by political science theory, Aspinall and Savirani, just to point out, which puts too much emphasis on the political elite. Political contracts should also be viewed differently from political electoral pulleys. ${ }^{61} 62$

${ }^{60}$ PKS Salatiga, “Akhiri Kampanye Nasional di Salatiga dan Solo PKS Targetkan Jateng Jadi Basis Baru,” Pkssalatiga.Com, 2014.

${ }^{61}$ Edward Aspinall, "Elections and the Normalization of Politics in Indonesia," South East Asia Research 13, no. 2 (2005): 117-156.

${ }^{62}$ Amalinda Savirani and Edward Aspinall, "Adversarial Linkages: The Urban Poor and Electoral Politics in Jakarta," Journal of Current Southeast Asian Affairs 3 (2017): 3-34. 
The study of Islamism should not rely solely on scholarly analysis employing academic speculation. The political shift in the Islamic world to a new direction, the emergence of Islamism, and the development of modern education with market values and democratic idioms in the Islamic world cannot be accepted as a new synthesis as a sign of alignment between Islamism and democracy or even wanting to replace it. It is true that in the context of democracy, the struggle for political space is allowed with the dynamics of the struggle for political space which must be constitutional. ${ }^{63}$ But precisely because it is allowed, the urban elites mobilize their people into local politics but not for the sake of democracy as a priority.

The Islamist and Christianist movement in a democracy cannot be understood as political participation alone. The urban space in which they live is a source of political economy that must be fought over through the new way of democracy, precisely it is very strong in it. Therefore, religion and politics which are democratically fabricated become the framework for a powerful social movement there. Scholars of religious studies need to advance their research on cities further as an ecology for the emergence of Islamism and Christianism on the new stage of democracy. Articulation on the geographic side as a place for ideology to be staged is the target of new research. How Islam, as well as Christianity, is interpreted as a political ideology that must be studied based on the empirical reality in which religion is practiced, not just a shift in academic paradigm or a good desires that arise from the purpose of preaching is wrapped in academic utterances.

\section{REFERENCES}

Afzaal, Ahmed. "The Origin of Islam as a Social Movement." Islamic Studies 42, no. 2 (2003).

Ahmad, Bilal. "Urbanization and Urban Development in the Muslim World: From the Islamic City Model to Megacities." GeoJournal 37, no. 1 (1995).

${ }^{63}$ Ali Akhbar Abaib Mas Rabbani Lubis, "Contestation on Political Space Between Islamism and Islamic Group in Presidential Election 2019," Al-Tahrir: Jurnal Pemikiran Islam 20, no. 2 (2020): 205-229. 
Ahnaf, Mohammad Iqbal. "Tiga Jalan Islam Politik di Indonesia: Reformasi, Refolusi dan Revolusi." Wawasan 1, no. 2 (2019).

Allen, John, Doreen Massey, and Michael Pryke. "Introduction." In Unsettling Cities: Movement/Settlement, edited by John Allen, Doreen Massey, and Michael Pryke. London and New York: Routledge in association with The Open University, 1999.

Amin, Husnul. "From Islamism to Post-Islamism: A Study of a New Intellectual Discourse on Islam and Modernity in Pakistan." The Erasmus University Rotterdam International Institute of Social Studies The Hague, The Netherlands, 2010.

Ansor, Muhammad. "Post-Islamism and the Remaking of Islamic Public Sphere in Post-Reform Indonesia." Studi Islamika 23, no. 3 (2016).

Aspinall, Edward. "Elections and the Normalization of Politics in Indonesia." South East Asia Research 13, no. 2 (2005).

Babbie, Earl. The Practice of Social Research. Boston, MA: Cengage Learning, 2015.

Badan Kerjasama Gereja-gereja Salatiga. "Members.” bkgssalatiga. com, 2015.

Barton, Greg. "Political Legitimacy in Indonesia: Islam, Democracy, and Good Governance,"(New York: Palgrave Macmillan, 2011)." In Political Legitimacy in Asia. Palgrave Series on Asian Governance, edited by J. Kane, HC. Loy, and H. Patapan, 2011.

Bayat, Asef. "Post-Islamist at Large." In Post-Islamis and the Changing Faces of Political Islam, edited by Asef Bayat. New York: Oxford University Press, 2013.

Bosworth, Clifford Edmund. "Editor's Introduction." In Historic Cities of the Islamic World, edited by Clifford Edmund Bosworth. Leiden and Boston: Brill, 2007.

Branson, Kayla. "Islamist Cyber-Activism: Contesting the Message, Redefining the Public." The Journal of North African Studies 19 , no. 5 (2014). 
Bubalo, Anthony, and Greg Fealy. Joining the Caravan?: The Middle East, Islamism, and Indonesia. Woollahra, Australia: Longueville Media, 2005.

Buchari, Sri Astuti. Kebangkitan Etnis Menuju Politik Identitas. Yogyakarta: Yayasan Obor Indonesia, 2014.

Dumper, Michael. "Introduction: The Urban Dimension of Religious Conflicts." In Contested Holy Cities: The Urban Dimension of Religious Conflicts, edited by Michael Dumper. London and New York: Routledge, 2019.

Hakh, Samuel Benyamin. "Peranan Orang Kristen dalam Pusaran Politik di Indonesia." Jurnal Ilmiah Musik dan Agama 2, no. 1 (2018).

Hardoy, J.E., and D. Satterhwaite. Small and Intermediate Urban Centers: Their Role in Regional and National Development in the Third World. London: Hooder and Stoughton, 1986.

Harmakaputra, Hans Abdiel. "Islamism and Post-Islamism 'NonMuslim' in Socio-Political Discourses of Pakistan, the United States, and Indonesia." Al-Jamiah 53, no. 1 (2015).

Haryatmoko. "Formalisme Hukum dan Rasa Keadilan." Kompas, 2015.

Hasan, Noorhaidi. Laskar Jihad, Islam, Militancy, and the Quest for Identity in Post-New Order Indonesia. New York: Cornell University, 2006.

Hidayaturrahman, Mohammad, and Sudarman. "Kyai and Political Relations Reconciling Politics and Religion in Indonesia." AlTahrir: Jurnal Pemikiran Islam 18, no. 2 (2018).

Jahroni, and Yairoh. "Interview.” Salatiga, 2016.

Khamami, Akhmad Rizqon. "Erdogan Versus Gulen: Perebutan Pengaruh antara Islam Politik Post-Islamis dengan Islam Kultural Apolitis." Al-Tahrir: Jurnal Pemikiran Islam 16, no. 2 (2016). 
Klinken, Gerry van. Communal Violence and Democratization in Indonesia: Smal Town Wars. London and New York: Routledge, 2007.

-. "Introduction: Democracy, Markets, and The Assertive Middle." In Search of Middle Indonesia: Middle Classes in Provincial Towns, edited by Gerry van Klinken and Ward Berenscho. Leiden and Boston: Brill, 2014.

Lalenoh, Ebenheser. “Interview.” Salatiga, 2015.

Liddert, P. van, and O. Verkoren. Small Towns and Beyond: Rural Transformation and Small Urban Centres in Latin America. Amsterdam: Thela Publishers, 1997.

Lubis, Ali Akhbar Abaib Mas Rabbani. "Contestation on Political Space Between Islamism and Islamic Group in Presidential Election 2019." Al-Tahrir: Jurnal Pemikiran Islam 20, no. 2 (2020).

McAdam, Doug, Sidney Tarrow, and Charles Tilly. Dynamics of Contention. Cambridge, UK, and New York: Cambridge University Press, 2001.

Muller, Dominic M. Islam, Politics, and Youth in Malaysia, the Pop-Islamist Reinvention of PAS. London and New York: Routledge, 2014.

Mumford, Lewis. The Culture of Cities. New York: Harcourt, 1938.

Nahari, Latif. “Interview.” Salatiga, 2014.

Nashir, Haedar. Islam Syariat: Reproduksi Salafiyah Ideologis di Indonesia. Bandung: Mizan Kerjasama dengan Maarif Institute for Culture and Humanity, 2013.

- Manifestasi Gerakan Tarbiyah: Bagaimana Sikap Muhammadiyah? Yogyakarta: Suara Muhammadiyah, 2007.

Nownes, Anthony J. Interest Groups in American Politics: Pressure and Power. New York: Routledge, 2013.

Parito, Alex Yustinus. "Interview.” Salatiga, 2015.

Parito, Petrus Yustinus. “Interview.” Salatiga, 2015. 
Prakosa, Abel Jatayu. Diskriminasi Racial di Kota Kolonial Salatiga 1442-1917. Semarang: Sinar Hidoep, 2017.

Rohana, Nono. "Interview.” Salatiga, 2014.

Sabine, G.H. A History of Political Thought. New York: Collier Books, 1959.

Salatiga, PKS. “Akhiri Kampanye Nasional di Salatiga Dan Solo PKS Targetkan Jateng Jadi Basis Baru.” Pkssalatiga.Com, 2014.

Sandeen, Ernest R. The Roots of Fundamentalism: British and American Millenarianism 1800-1930. Chicago: University of Chicago Press, 2008.

Saunders, Peter. Social Theory and the Urban Question. London and New York: Routledge, 1989.

Savirani, Amalinda, and Edward Aspinall. "Adversarial Linkages:

The Urban Poor and Electoral Politics in Jakarta." Journal of Current Southeast Asian Affairs 3 (2017).

Schragger, Richard. City Power: Urban Governance in a Global Age. New York: Oxford University Press, 2016.

Singgih, Emmanuel Gerrit. Iman dan Politik dalam Era Reformasi di Indonesia. Jakarta: BPK Gunung Mulia, 2004.

Small, Albion W. "The Meaning of the Social Movement." American Journal of Sociology 3, no. 3 (1897).

Sudirja. "Interview." Salatiga, 2016.

Sugito, Stefanus. "Interview.” Salatiga, 2016.

Sukary, Matheus. "Interview.” Salatiga, 2015.

Sullivan, Andrew. "Christianity vs Christianism, Love vs Power." The Atlantic, 2009.

Sunari, Yusuf. "Interview.” Salatiga, 2015.

Suryanto. "Interview." Salatiga, 2014.

Suwarno, Fauzi Untung, and Wife. "Interview.” Salatiga, 2016. 
Syarif, Zainuddin. "Pergeseran Perilaku Politik Kiai dan Santri di Pamekasan Madura." Al-Tahrir: Jurnal Pemikiran Islam 16, no. 2 (2016).

Tambunan, Elia. "Indonesian Islamism: The War of Islamic Literacy from Millenarism to Radicalism." Akademika 24, no. 1 (2019).

Therborn, Goran. Cities of Power: The Urban, The National, The Popular, The Global. London and New York: Verso, 2017.

Tilly, Charles. Contentious Performances. Cambridge: Cambridge University Press, 2008.

Tompkins, Joanne. Unsettling Space: Contestations in Contemporary Australian Theatre. New York: Palgrave Macmillan, 2006.

Tule, Philipus. "Religious Conflicts and a Culture of Tolerance: Paving the Way for Reconciliation in Indonesia." In Prosiding Simposium Internasional Jurnal Antropologi Indonesia I. Makassar, 2000.

Wahid, Abdurrahman. "Pengantar Editor: Musuh dalam Selimut." In Ilusi Negara Islam: Ekspansi Gerakan Islam Transnasional di Indonesia, edited by Abdurrahman Wahid. Jakarta: The Wahid Institute dan Maarif Institute, 2009.

Zamsiri. “Interview.” Salatiga, 2016. 